\title{
Organizational Culture: The Perspectives of New Hires and Existing Employees of a Pharmaceutical Company in Thailand
}

\author{
Suparat Yaoprukchai ${ }^{1}$ \& U-maporn Kardkarnklai ${ }^{1}$ \\ ${ }^{1}$ Western Languages Department, Faculty of Humanities, Srinakharinwirot University, Bangkok, Thailand \\ Correspondence: U-maporn Kardkarnklai, Western Languages Department, Faculty of Humanities, \\ Srinakharinwirot University, Bangkok 10110, Thailand. E-mail: ukard252@gmail.com
}

Received: May 7, 2014 Accepted: May 27, 2014 Online Published: June 24, 2014

doi:10.5539/ass.v10n14p224

URL: http://dx.doi.org/10.5539/ass.v10n14p224

\begin{abstract}
The recent increase in new hires by Thai pharmaceutical companies due to the unstable employment within the global pharmaceutical industry has led to a rise in human resources management expenditures. Organizational culture has become a central focus of many researchers with the aim to propose strategies for maintaining employees. The present study assessed the organisational culture of a pharmaceutical company in Thailand. In addition, the congruency between the organizational culture of new hires and existing employees was investigated. The participants were 68 employees ( 15 new hires and 58 existing employees) of one multinational pharmaceutical company in Thailand. The findings demonstrated that the current and preferred organizational cultures of the studied pharmaceutical company were dominated by a "Clan" culture characterized by a family-like workplace, a parent-like relationship between organizational leaders and subordinates, and teamwork-focused values. Both new hires and existing employees rated "Clan" as the dominant organizational culture, which indicated organizational culture congruence between them. The present study facilitated a better understanding of the organizational culture of the Thai pharmaceutical industry. The findings contributed to the useful resources of a Thai pharmaceutical company's organizational culture, which are necessary for the development of proper orientation programs and activities to improve the retention of new hires.
\end{abstract}

Keywords: competing values framework, organizational culture, organizational culture assessment instrument, pharmaceutical

\section{Introduction}

\subsection{Background of the Study}

Employment in the Thai pharmaceutical industry has recently faced instability. One of the roots causes lies in the global downsizing of leading multinational pharmaceutical companies to reduce expenses. Since 2009, these companies have dismissed over 100,000 employees in their subsidiaries worldwide, including their branches in Thailand (Burrill \& Company, 2011). Some firms have decided to continue these layoffs. For example, Merck, which is the oldest pharmaceutical and chemical company, plans to terminate 8,500 positions in its international workforce (Reuters, 2013). This tremendous downsizing impacts employee turnover in pharmaceutical companies in Thailand because the dismissed workers must find new jobs in other pharmaceutical companies. Hence, the number of new hires has significantly increased in some pharmaceutical companies.

The increase of new hires in connection with business expenditures has become a growing concern in the pharmaceutical industry. The expenses for new hires include compensations, training costs, and costs associated with workspace. With large investments made in new hires, pharmaceutical companies have to retain them to actualize a return on the investments. However, nearly 50\% of turnover occurs during the employee's first year on the job (Dan \& Petersen, 1984). Moreover, an organization is estimated to lose $\$ 1,400$ per hire because of the resignation of employees during their first year of employment (Sutarjo, 2011). To reduce the business expenses associated with new hires, pharmaceutical companies concentrate on organizational culture because it could play a critical role in a company's ability to retain employees.

Organizational culture reinforces employee commitment to the company by its contribution to supporting employee recruitment, orientation, and job satisfaction. Organizational culture, which is unique for each company, is a pattern of collective values, beliefs, attitudes, and norms of the members in the organization 
(Odom, Boxx, \& Dunn, 1990). The assessment of organizational culture reveals the organizations' characteristics in various organizational dimensions such as language, leadership styles, and management styles (Cameron \& Quinn, 2006). Therefore, the knowledge of organizational culture is beneficial for the selection of the right job applicant. In this regard, a pharmaceutical company could screen for a job candidate whose values are compatible to those of the organizational culture. Furthermore, the information on organizational culture is given to an employee during an orientation, which helps new hires adapt to the organizational culture. In particular, an organizational leader could use the preferred organizational culture to improve job satisfaction and workplace relationships, which are factors that are ranked the top three causes of employee resignation in Thailand (The Human Capacity on Building Institute, 2012). Overall, organizational culture is comparable to a binding mechanism that holds members in the organization together (Cameron \& Quinn, 2006). Hence, observing and understanding organizational culture are critical to pharmaceutical companies in Thailand.

The need to observe organizational culture within the context of Thailand's pharmaceutical industry is paramount because of the lack of empirical research on the dominant types of organizational culture and the advent of the ASEAN Economic Community (AEC) in 2015. First, the dominant types of organizational culture are required for better understanding of the organizations in the pharmaceutical industry. However, less attention had been paid to measuring the characteristics of organizational culture in pharmaceutical organizations in Thailand. Previous studies on the organizations in the Thai pharmaceutical industry emphasize examining the relationships between organizational culture and different variables such as job satisfaction, organizational learning, and information system characteristics (Aswapokee, 2007; Chimthai, 2009; Dilokgomon, 2003). Hence, an empirical study with the goal of assessing the organizational culture within this context is necessary.

Second, the coming of the AEC could aggravate the employee turnover problem in the organizations in Thailand's pharmaceutical industry. According to the AEC agreement, the free flow of skilled labors is allowed in ASEAN countries ( $\mathrm{Li}, 2011$; Thailand Board of Investment, 2011). This free flow potentially leads to an increase in employee turnover, which propagates the existing problem within the pharmaceutical industry. Therefore, the organizations in Thailand's pharmaceutical industry should prepare to handle the potential employee turnover from the advent of the AEC by utilizing helpful information from organizational culture assessments.

According to the two aforementioned reasons, it is critical to assess organizational culture in pharmaceutical company in Thailand. This study attempts to measure the organizational culture of the pharmaceutical company in two situations, namely, the current and the preferred organizational cultures. The current organizational culture refers to the perceived culture within the pharmaceutical company at the time of the investigation, while the preferred organizational culture is the culture that employees prefer that the pharmaceutical company adopt within the next five years. Additionally, this study investigates the organizational culture congruence between new hires (i.e., new employees whose tenure in the company is $\leq 12$ months) and existing employees (i.e., an employee who has been working with the pharmaceutical company for more than 12 months).

\subsection{Relevant Scholarship}

A literature review about (a) employee turnover and new hires in the pharmaceutical industry, (b) organizational culture, and (c) previous research on organizational culture in the pharmaceutical industry will be presented.

\subsubsection{Employee Turnover and New Hires in the Pharmaceutical Industry}

The pharmaceutical industry has been recognized as an industry that has very high employee turnover rates. In 2006, the turnover rate in the pharmaceutical industry reached $16.9 \%$, which is significantly higher than the average $11.9 \%$ turnover rate associated with other industries (Wilton, 2006). According to a survey in India in 2010 , the pharmaceutical industry was the sector most affected by employee turnover with an attrition rate of 35\% (Dhotre, 2010). Furthermore, the employee turnover situation intensified after 2009, as large multinational pharmaceutical enterprises have lain off over 100,000 jobs in their subsidiaries (Burrill \& Company, 2011). Hence, there was a significant increase in the number of new hires in medium and small pharmaceutical companies. Accordingly, as a critical resource, pharmaceutical companies should pay attention to new hires.

New hires are at risk of leaving a company, which leads to increased business expenses. The term "new hires" refers to employees who have recently accepted employment in an organization and have a tenure ranging from 1 to 12 months (Yang, 2008). Employee turnover is a serious problem among new hires, as nearly half of them leave the company within the first year of their tenure. In fact, the highest turnover occurs during the first four weeks of employment (Dan \& Petersen, 1984; Yang, 2008). The resignation of new hires exacerbates turnover problems in the pharmaceutical industry. The obvious negative effects from turnover are on business expenses such as the cost of recruitment to find replacement workers (e.g., costs of job advertisements, English 
proficiency tests, and medical examinations) and the costs associated with training new hires so that they possess the requisite knowledge and skills to perform their jobs. As a result of the expenses associated with hiring and training, a new hire can exceed $50 \%$ of the employee's annual salary. It is incumbent upon the management of pharmaceutical companies to establish strategies to retain new hires (Ongori, 2007).

Pharmaceutical companies retain new hires by identifying the reasons for their resignation and by developing the proper strategies to address them. New hires frequently leave a company due to (a) incompatibility between their expectations and the reality of the new workplace and (b) incompatibility with supervisors, colleagues, and customers because new hires may behave and communicate in ways that do not conform to the new organizational culture (Hildebrand, 2010; Yang, 2008). The recommended strategy to alleviate these problems is to measure organizational culture, which allows job seekers to understand the organizational culture prior to accepting employment. Doing so would reduce turnover rates because job seekers whose values mismatch with those of the organizational culture would not apply for a position (McShane \& Von Glinow, 2002). Additionally, new hires should be adequately educated about the organizational culture so that they can appropriately adapt to the organization and establish positive workplace relationships (Sutarjo, 2011).

Understanding an organizational culture is one of the principal strategies behind retaining new employees. Organizational culture has become one of the most actively studied areas within the fields of organizational behavior and human resources management since the early 1980s (Deshpande \& Webster, 1989). Vandenberghe (1999) observed the relationship between organizational culture and turnover in nurses operating in Belgian health care organizations and concluded that the new hires whose preferred values fit with the organizational culture tended to stay with the organization. Silverthorne (2004) reported the strong influences of person-organization (P-O) fit on employee job satisfaction and on organizational commitment as well as the negative impacts of these factors on turnover rates. Thus, measuring organizational culture is necessary to understand the P-O fit between new hires and the organization.

Sutarjo (2011) discussed ten ways to manage P-O fit. A measure of the "ideal" and the "actual" organizational cultures is a strategy to reduce employee turnover. The ideal organizational culture reflects the preferred values of the organization and supports a leader in establishing the proper organizational objectives. In contrast, the actual organizational culture is important for socialization, which is a process by which the organization communicates its values, norms, and ways of operating, thus helping new hires to assimilate to the organizational culture. Socialization effectively enhances employee retention because it fosters the employee's sense of organizational belonging and causes a strong P-O fit.

Due to the influence on retaining new hires and reducing employee turnover, a pharmaceutical company should give precedence to its organizational culture.

\subsubsection{Organizational Culture}

Numerous experts have proposed definitions of organizational culture ranging from simple to complex. Organizational culture can be easily defined as "the way things are done around here" (Martin, 2006) or "the characteristic or personality of the organization" (Zaheer, Rehman, \& Ahmad, 2006). A more formal definition of organizational culture was proposed by Schein (2004):

"Organizational culture is a pattern of shared basic assumptions that was learned by a group as it solved its problems of external adaptation and internal integration that has worked well enough to be considered valid and, therefore, to be taught to new members as the correct way you perceive, think, and feel in relation to those problems."

Notwithstanding the numerous definitions that exist, there is no consensus regarding a single exact definition of organizational culture. Hence, this study defines organizational culture by applying Schein's definition because it is one of the most frequently cited in the literature. Furthermore, Aydogdu and Asikgil (2011) conclude that Schein's definition employs a systematic approach to describing the key components of organizational culture (i.e., values, beliefs, and behaviors), which are mentioned in other bodies of literature as well (as presented in Table 1). 
Table 1. Definitions of organizational culture

\begin{tabular}{|c|c|c|}
\hline Author & Year & Definitions of Organizational Culture \\
\hline Harrison & 1993 & $\begin{array}{l}\text { The distinctive constellation of beliefs, values, work styles, and relationships that distinguish one } \\
\text { organization from another. }\end{array}$ \\
\hline Brown & 1998 & $\begin{array}{l}\text { The pattern of beliefs, values and learned ways of coping with experience that have developed } \\
\text { during the course of an organization's history, and which tend to be manifested in its material } \\
\text { arrangements and in the behaviors of its members. }\end{array}$ \\
\hline Coreil et al. & 2001 & $\begin{array}{l}\text { Ways of thought and behavior that characterize a social group that can be learned by socialization } \\
\text { process and persist through time. }\end{array}$ \\
\hline $\begin{array}{l}\text { Cameron and } \\
\text { Quinn }\end{array}$ & 2006 & $\begin{array}{l}\text { An enduring set of values, beliefs, and assumptions that characterize organizations and their } \\
\text { members. }\end{array}$ \\
\hline Martin & 2006 & $\begin{array}{l}\text { A deeply rooted value that shapes the behavior of the individuals within the group. Organizational } \\
\text { culture consists of an organization's shared values, symbols, behaviors, and assumptions. }\end{array}$ \\
\hline Aydogdu & 2011 & $\begin{array}{l}\text { Organizational culture includes what is valued, the dominant leadership style, the language and } \\
\text { symbols, the procedures and routines, and the definitions of success that characterizes an } \\
\text { organization. }\end{array}$ \\
\hline
\end{tabular}

Overall, organizational culture in this study refers to the intangible characteristics of an organization. It is a pattern of mutual basic assumptions, beliefs, and values held by the members of the organization. Organizational culture can be taught and learned by members so that all members of the organization perceive, think, and behave accordingly.

Organizational culture can be assessed by various instruments. Jung et al. (2009) systematically reviewed the literature and identified 70 instruments for exploring organizational culture. Although various instruments are available, no single ideal fits all studies. Each instrument is different in its purpose for development, measured cultural dimensions, methodological approaches, and data-generating methods. Therefore, selection of the appropriate tool should be concerned with (a) the alignment between the study's objectives and the instrument's capability, (b) the instrument's transferability, which relates to the similarities between the originating and receiving contexts (e.g., technical requirements, the necessary skill of data collectors and interpreters), (c) the available resources (i.e., time and funds), and (d) the instrument's reliability and validity.

The Organizational Culture Assessment Instrument (OCAI) was the instrument selected for this study for four reasons. First, the OCAI appropriately addresses the research questions, which aim to measure the organizational culture of a pharmaceutical company in Thailand. It identifies six important organizational culture dimensions: Dominant characteristics, Organizational leadership, Management of employees, Organizational glue, Strategic emphasis, and the Criteria of success (Cameron \& Quinn, 2006).

Second, the OCAI should be highly applicable and transferable in this study. The OCAI's transferability has been demonstrated in research conducted in more than 10,000 organizations worldwide (OCAI Online, n. d.). In the context of organizations in Thailand, the OCAI has been applied to various organizations, including government institutions, private companies, banks, and educational institutions. Third, with respect to available resources, the OCAI is a practical and free-of-charge tool which requires only 10 to 15 minutes completing.

Finally, the OCAI contains two important qualities of a questionnaire: reliability and validity. Cameron and Quinn (2006) conclude from numerous studies that the OCAI measures what it claims to measure (i.e., validity) and that it measures consistently every time (i.e., reliability). The OCAI's reliability exceeds the standard level of most of the commonly used instruments in the social and organizational sciences. For instance, a study by Yeung, Brockbank, and Ulrich (1991) (as cited by Cameron \& Quinn, 2006, p. 154), which included 10,300 executives from 1,064 businesses, found that the Cronbach's alpha coefficients of the OCAI were valued over 0.7. In conclusion, the OCAI is consciously selected to assess organizational culture in this study.

The OCAI is based on the Competing Values Framework (CVF). The framework was developed from a statistical analysis of 39 indicators of effective organizations to create two major dimensions: a) Flexibility and discretion versus Stability and control and b) Internal orientation and integration versus External orientation and differentiation. Because these dimensions are based on the opposite or competing characteristics of the criteria, the framework was termed "the Competing Values Framework". The CVF generates four organizational culture types: (a) Clan, (b) Adhocracy, (c) Market, and (d) Hierarchy (Cameron \& Quinn, 2006). Each type of organizational culture is present in one quadrant of the CVF (see Figure 1). 


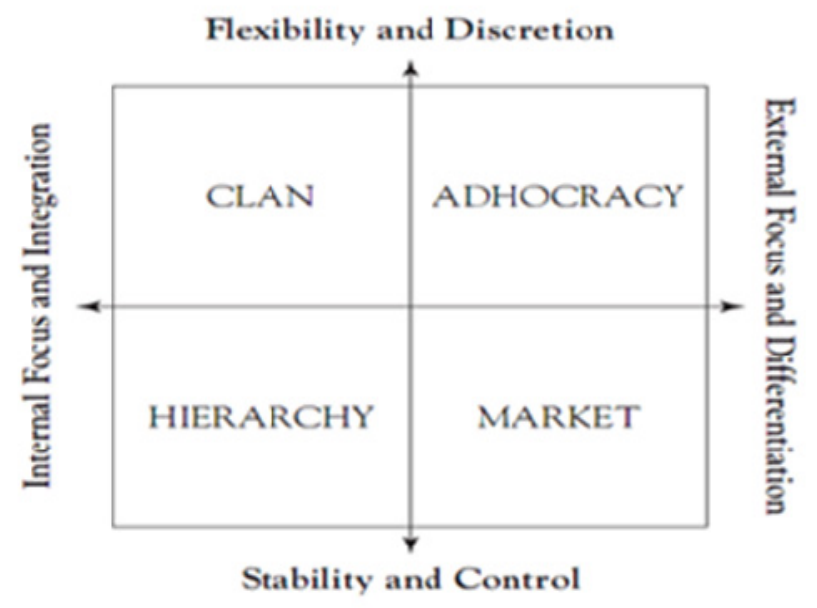

Figure 1. The competing values framework and types of organizational culture (Cameron \& Quinn, 2006, p. 35)

The four types of organizational culture present distinct characteristics:

1) Clan culture creates a family-type organization, which appears more similar to an extended family than to an economic entity. A clan-oriented organization values teamwork, commitment, and communication. Leaders are thought of as mentors or parents. The organization emphasizes the long-term benefits of individual development. Loyalty, tradition, and collaboration bind members together. The internal climate and employees are the criteria for success.

2) Adhocracy culture is a dynamic, entrepreneurial, and creative workplace. Effective leadership is visionary, innovative, and risk-oriented. The long-term emphasis is on rapid growth, acquiring new resources and being the leader in the development of new knowledge, products, and/or services. Hence, readiness for change and for meeting new challenges is critical. The organizational glue is a commitment to experimentation and innovation. Success is realized when the organization produces unique products and/or services.

3) Market culture focuses on external environments such as competitors, suppliers, and customers. As such, this culture is a results-oriented workplace where the core values are competitiveness and productivity. Leaders are hard-driving producers, directors, and competitors. The long-term concern is on competitive actions and achieving targets. An organization's success is determined by its market share and market penetration. The organizational glue is an emphasis on winning through economic market mechanisms.

4) Hierarchy culture focuses on the internal orientation and the stability of the organization. Effective leaders are good coordinators, organizers, and experts. The long-term concerns are stability, predictability, and efficiency. Formal rules and policies hold the organization together.

In conclusion, the CVF creates four organizational culture types: Clan, Adhocracy, Market, and Hierarchy. By using the OCAI, an organization can identify its organizational culture and acquire better understanding in terms of six organizational culture dimensions including dominant organizational culture, leadership styles, management styles, binding mechanisms, strategic emphasis, and criteria of success.

\subsubsection{Previous Research on Organizational Culture in the Pharmaceutical Industry Setting}

Previous studies conducted on organizations in Thailand have paid less attention to identifying the dominant organizational culture. These studies have mainly investigated the relationship between organizational culture and various determinants. For example, Dilogkomol (2003) studied the learning organization and organizational culture of Better Pharma Company, a veterinary medicine manufacturer. It applied four frameworks developed by Schein (2004), Boyett (2000), Daft (2001), and Denison (2000) and found that Better Pharma Company's organizational culture dimensions (i.e., adaptability, involvement, and consistency) were at moderate levels.

Aswapokee (2007) investigated the impact of information system characteristics and organizational culture on job satisfaction from Medical Sales Representatives and Product Managers of four multinational pharmaceutical companies in Thailand. Jones et al. (2004)'s framework and questionnaire were adapted to assess organizational culture dimensions. The study concluded that organizational culture influences job satisfaction and information system characteristics. 
Chimthai (2009) reported the relationship between organizational culture, organizational commitment, and the effectiveness of employee performance among staff employed by the Thai Government Pharmaceutical Organization. The study applied the contrasting organizational culture framework (i.e., organizational culture types A and B) to measure four dimensions including control, organizing, planning, and leadership. The findings indicated that each organizational culture dimension was at a moderate level.

Previous studies conducted in pharmaceutical companies in Turkey and India reported the dominant type of organizational culture. Demir, Unnu and Erturk (2010) explored the organizational cultures of a pharmaceutical company in Turkey by using the CVF. The current and preferred organizational culture of the Turkish pharmaceutical company was Hierarchy and Clan, respectively. Gupta (2011) examined the organizational culture of organizations in Indian pharmaceutical industry by delivering the OCAI through electronic mail. The dominant organizational culture type among pharmaceutical companies in India was the Adhocracy culture.

Nagashekhara and Agil (2012) concluded that organizational culture strongly influences the ethical behavior of medical representatives in Indian pharmaceutical companies. Furthermore, a better organizational culture was one of the critical factors of creating more desirable ethical practices among Indian medical representatives. As the framework for observing organizational culture was not mentioned, the organizational culture types and characteristics of the included companies were not available.

A literature review indicates that organizational culture has attracted interest in the pharmaceutical context. The aforementioned studies were different in three main factors: (a) the applied frameworks, (b) the dimensions of organizational culture investigated, and (c) the instruments of data collection. In Thailand, the organizational cultures of pharmaceutical companies were reported at the moderate level (Chimthai, 2009; Dilokgomon, 2003). Findings from these previous studies may be unclear to explain characteristics of the Thai pharmaceutical industry. Therefore, this study intended to fill the gap by measuring the dominant organizational culture of a pharmaceutical company in Thailand.

\section{Method}

This section presents the methodology: (a) the selection of the organization, (b) participants in this study, (c) research instrument, (d) data collection and (e) data analysis.

\subsection{Selection of the Organization}

TRB Chemedica (Thailand) limited was selected to be included in the sample by the purposive sampling technique from the population of 171 pharmaceutical companies in Thailand. It was determined to be a good representative because the organizational culture has never been explored after establishment for over 20 years. A measurement of organizational culture could be beneficial for organizational management including for the development of a strategy to reduce employee turnover. Recently, the company has confronted high employee turnover as new hires continuously increased from $11 \%$ in 2010 to $27 \%$ in 2013 . There were 21 new hires in 2013, which make up almost one-third of the total employees (Jitsook N., personal communication, 2013).

\subsection{Participant Characteristics}

All TRB Chemedica (Thailand)'s employees voluntarily decided whether to participate in this study. The total sample was comprised of 78 Thai employees who worked in one of the following divisions:

1) Department of Administration and Finance: Employees were responsible for accounting, human resources management, product distribution, bill collection, computer system, and housekeeping.

2) Scientific and Regulatory Affairs Department: Employees were accountable for providing product information, ensuring that the clinical research conducted in Thailand complies with the good clinical practices, and ensuring that all company's activities conform to the government regulations.

3) Ophthalmic Business Unit: Employees were accountable for marketing and selling artificial tears, eyelid cleansers, and devices for eye surgeries.

4) Orthopedic Business Unit: Employees were responsible for marketing and selling medicines used in treating osteoarthritis.

5) Indochina Business Unit: Employees took care of customers in the Indochina area.

\subsection{Instrument of the Study}

The organizational culture assessment instrument (OCAI) is often used to measure organizational culture; however, it is in English, which could be difficult for some respondents. Hence, this study adopts the OCAI questionnaire translated from English to Thai by Niwat Chotiwongse (Chotiwongse, 2001). This translated 
OCAI was successfully applied in a Thai context, and the Cronbach's alpha was 0.857 (Poonsawat, 2005).

The questionnaire consists of two parts. The first part collects participants' demographic data (i.e., sex, age, level of education, working position and department, and length of employment with the company). The second part collects data for the assessment of a company's organizational cultures. The OCAI is a 24-item questionnaire consisting of six topics, each containing four statements (A to D). This study applied a five-point Likert scale: (1) strongly disagree, (2) disagree, (3) neutral, (4) agree, and (5) strongly agree.

Pilot testing of the questionnaire demonstrated high reliability. The questionnaire was tried out on 27 employees in another pharmaceutical company in Thailand. The Cronbach's alpha scores for current organizational culture were: Clan $=0.878$, Adhocracy $=0.702$, Market $=0.826$, Hierarchy $=0.805$, and total $=0.936$. In addition, the Cronbach's alpha scores for the preferred organizational culture were: Clan $=0.893$, Adhocracy $=0.739$, Market $=0.763$, Hierarchy $=0.824$, and total $=0.938$. The alpha coefficients were higher than 0.7 ; therefore, the questionnaire was highly reliable and appropriate to be administered to the sample group.

\subsection{Data Collection}

The questionnaire was distributed to 78 employees at the office of TRB Chemedica (Thailand) limited in July 2013. After one week, 69 questionnaires were returned giving a response rate of $88.5 \%$. One questionnaire was abandoned because the respondents did not complete the entire questionnaire.

\subsection{Data Analysis}

Data analysis was carried out by analyzing the demographic data using descriptive statistics and calculating the average scores obtained from the OCAI.

\section{Results}

This section presents the findings to address the research questions about the organizational culture of the pharmaceutical company in Thailand. It contains the characteristics of participants and the organizational culture of the pharmaceutical company.

\subsection{Characteristics of the Participants}

A total of 68 respondents of TRB Chemedica (Thailand) Limited completed the questionnaire. Approximately $79 \%$ of the respondents were female and $66.18 \%$ of them had earned Bachelor's degrees. Most of respondents were aged between 31 to 40 years old $(57.35 \%$ of the respondents). In terms of department, the respondents working in the Ophthalmic Business Unit were at the highest number (33.82\% of the respondents). The average period of employment with TRB Chemedica (Thailand) Limited was five years, and $22.06 \%$ of the respondents were new hires whose job tenure within the company was not more than 12 months. The demographic data on respondents were summarized in Table 2.

Table 2. Characteristics of participants

\begin{tabular}{|c|c|c|}
\hline Characteristics & Number of participants & Percent \\
\hline \multicolumn{3}{|l|}{ Sex } \\
\hline Male & 14 & 20.59 \\
\hline Female & 54 & 79.41 \\
\hline \multicolumn{3}{|l|}{ Age } \\
\hline $21-30$ & 18 & 26.47 \\
\hline $31-40$ & 39 & 57.35 \\
\hline $41-50$ & 9 & 13.24 \\
\hline$>50$ & 2 & 2.94 \\
\hline \multicolumn{3}{|l|}{ Educational level } \\
\hline Lower than Bachelor's degree & 7 & 10.29 \\
\hline Bachelor's degree & 45 & 66.18 \\
\hline Master's degree & 16 & 23.53 \\
\hline \multicolumn{3}{|l|}{ Department } \\
\hline Administration \& Finance & 15 & 22.06 \\
\hline Scientific \& Regulatory Affairs & 5 & 7.35 \\
\hline Ophthalmic Business Unit & 23 & 33.82 \\
\hline
\end{tabular}




\begin{tabular}{|c|c|c|}
\hline Characteristics & Number of participants & Percent \\
\hline Orthopedic Business Unit & 22 & 32.35 \\
\hline Indochina Unit & 3 & 4.41 \\
\hline \multicolumn{3}{|l|}{ Length of employment } \\
\hline$\leq 12$ months & 15 & 22.06 \\
\hline$>12$ months & 53 & 77.94 \\
\hline
\end{tabular}

\subsection{Organizational Culture of the Pharmaceutical Company}

The findings related to the current and preferred organizational cultures of the pharmaceutical company in Thailand were presented in three perspectives: all employees, the new hires, and the existing employees.

\subsubsection{Organizational Culture of All Employees}

The findings obtained from all respondents contributed to deepening the understanding of the current and preferred organizational cultures of this particular pharmaceutical company in Thailand.

Table 3. The organizational culture of all employees

\begin{tabular}{|c|c|c|c|c|c|c|c|c|}
\hline \multicolumn{9}{|l|}{ Organizational Culture } \\
\hline $\begin{array}{l}\text { Dimensions of } \\
\text { Organizational Culture }\end{array}$ & $\begin{array}{l}\text { Current } \\
\text { Clan }\end{array}$ & $\begin{array}{l}\text { Preferred } \\
\text { Clan }\end{array}$ & $\begin{array}{l}\text { Current } \\
\text { Adhocracy }\end{array}$ & $\begin{array}{l}\text { Preferred } \\
\text { Adhocracy }\end{array}$ & $\begin{array}{l}\text { Current } \\
\text { Market }\end{array}$ & $\begin{array}{l}\text { Preferred } \\
\text { Market }\end{array}$ & $\begin{array}{l}\text { Current } \\
\text { Hierarchy }\end{array}$ & $\begin{array}{l}\text { Preferred } \\
\text { Hierarchy }\end{array}$ \\
\hline $\begin{array}{l}\text { Dominant Characteristics } \\
\text { of Organization }\end{array}$ & 4.13 & 4.70 & 3.40 & 3.16 & 3.59 & 3.94 & 3.15 & 3.26 \\
\hline $\begin{array}{l}\text { Organizational } \\
\text { Leadership }\end{array}$ & 4.29 & 4.68 & 4.29 & 4.60 & 3.78 & 3.90 & 4.09 & 4.62 \\
\hline $\begin{array}{l}\text { Management of } \\
\text { Employees }\end{array}$ & 4.16 & 4.71 & 2.99 & 3.06 & 3.04 & 3.00 & 4.10 & 4.65 \\
\hline Organizational Glue & 4.03 & 4.65 & 4.07 & 4.62 & 3.99 & 4.38 & 3.74 & 4.26 \\
\hline Strategic Emphases & 3.82 & 4.66 & 3.59 & 4.25 & 3.62 & 4.16 & 4.04 & 4.63 \\
\hline Criteria for Success & 4.16 & 4.84 & 3.99 & 4.62 & 3.72 & 3.99 & 3.88 & 4.46 \\
\hline $\begin{array}{l}\text { Overall Organizational } \\
\text { Culture }\end{array}$ & 4.10 & 4.71 & 3.72 & 4.05 & 3.62 & 3.89 & 3.83 & 4.31 \\
\hline
\end{tabular}

Table 3 showed the scores of each organizational culture dimension and the overall organizational culture scores. The scores of the current and perceived types of organizational culture from the highest to the lowest were Clan (4.10), Hierarchy (3.83), Adhocracy (3.72), and Market (3.62). The scores of preferred organizational culture types were Clan (4.71), Hierarchy (4.31), Adhocracy (4.05), and Market (3.89). The current and preferred organizational cultures of TRB Chemedica (Thailand) Limited were similarly dominated by Clan, which obtained the highest score. However, Market culture obtained the lowest score for current and preferred situations. 


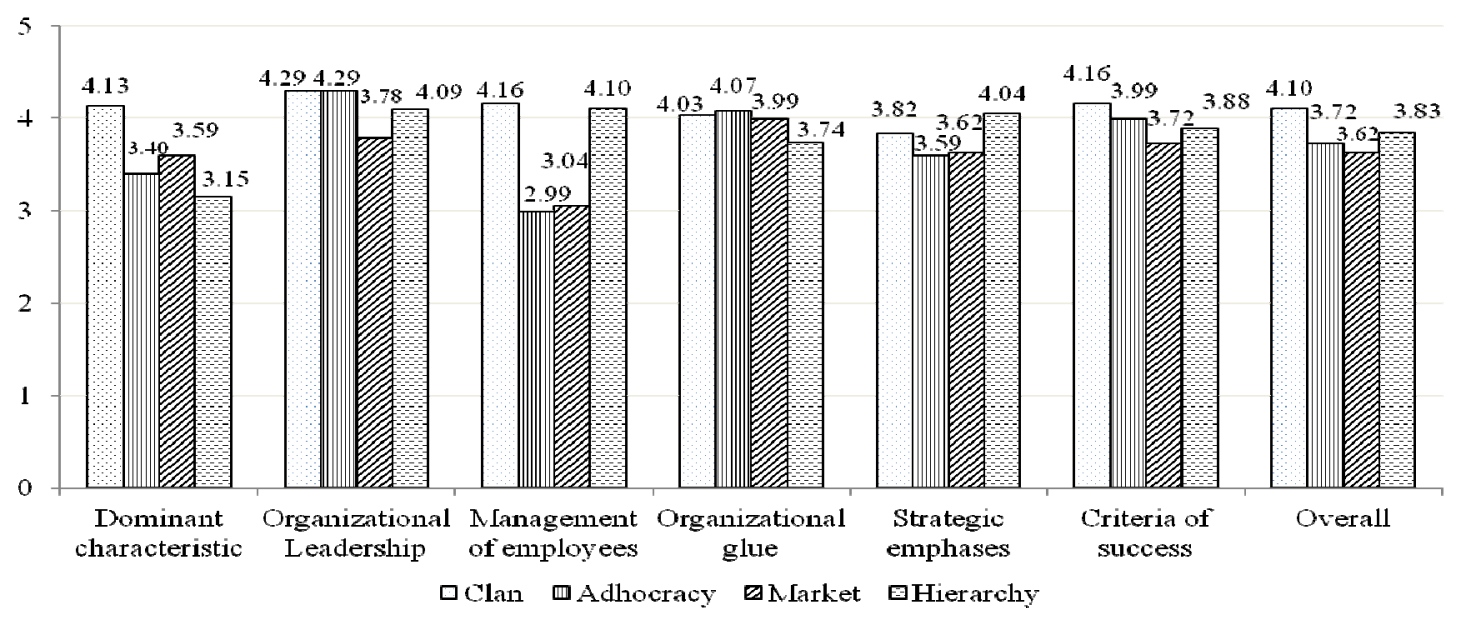

Figure 2. The current organizational culture of all employees

An analysis of six organizational culture dimensions in the current situation showed that each dimension was dominated by a different type of organizational culture (Figure 2). Clan was dominated in four organizational culture dimensions: the dominant characteristics of organization (4.13), organizational leadership (4.29), management of employees (4.16), and criteria of success (4.16). Two organizational culture dimensions were dominated by other organizational culture types. The organizational glue was dominated by Adhocracy culture (4.07), and the strategic emphases dimension was dominated by Hierarchy culture (4.04). In sum, the dominant types of six organizational culture dimensions in the current situation were incongruent.
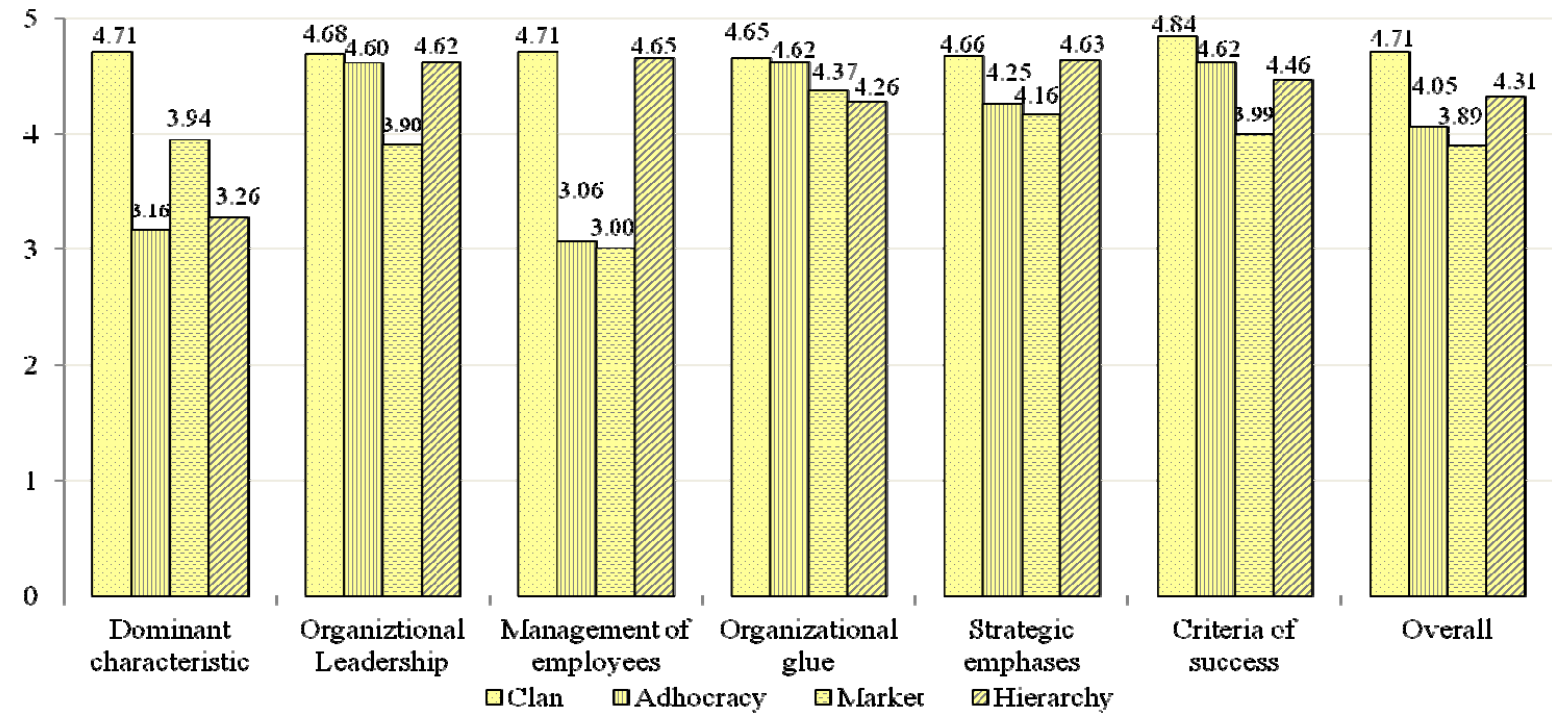

Figure 3. The preferred organizational culture of all employees

In contrast to the current situation, the preferred organizational culture of all employees presented the congruency of all dimensions. The findings in Figure 3 demonstrated that all employees preferred Clan culture in all organizational culture dimensions. The score of Clan culture were 4.71 for the dominant characteristics of the organization, 4.68 for organizational leadership, 4.71 for management of employees, 4.65 for organizational glue, 4.66 for strategic emphases, and 4.84 for criteria of success.

\subsubsection{Organizational Culture of New Hires}

Fifteen new hires of TRB Chemedica (Thailand) Limited answered the questionnaire about the current and preferred organizational cultures, and the results were summarized in Table 4. 
Table 4. The organizational culture of new hires

\begin{tabular}{|c|c|c|c|c|c|c|c|c|}
\hline \multicolumn{9}{|l|}{ Organizational Culture } \\
\hline $\begin{array}{l}\text { Dimensions of } \\
\text { Organizational Culture }\end{array}$ & $\begin{array}{l}\text { Current } \\
\text { Clan }\end{array}$ & $\begin{array}{l}\text { Preferred } \\
\text { Clan }\end{array}$ & $\begin{array}{l}\text { Current } \\
\text { Adhocracy }\end{array}$ & $\begin{array}{l}\text { Preferred } \\
\text { Adhocracy }\end{array}$ & $\begin{array}{l}\text { Current } \\
\text { Market }\end{array}$ & $\begin{array}{l}\text { Preferred } \\
\text { Market }\end{array}$ & $\begin{array}{l}\text { Current } \\
\text { Hierarchy }\end{array}$ & $\begin{array}{l}\text { Preferred } \\
\text { Hierarchy }\end{array}$ \\
\hline $\begin{array}{l}\text { Dominant Characteristics } \\
\text { of Organization }\end{array}$ & 4.13 & 4.87 & 3.27 & 2.53 & 3.40 & 3.73 & 3.27 & 3.00 \\
\hline Organizational Leadership & 4.33 & 4.67 & 4.33 & 4.60 & 4.13 & 4.07 & 4.27 & 4.73 \\
\hline $\begin{array}{l}\text { Management of } \\
\text { Employees }\end{array}$ & 4.53 & 4.93 & 3.07 & 2.87 & 3.07 & 2.53 & 3.87 & 4.60 \\
\hline Organizational Glue & 3.67 & 4.67 & 3.80 & 4.53 & 3.93 & 4.40 & 3.53 & 4.13 \\
\hline Strategic Emphases & 3.73 & 4.73 & 3.47 & 4.13 & 3.53 & 4.00 & 3.87 & 4.60 \\
\hline Criteria for Success & 3.87 & 4.87 & 3.80 & 4.60 & 3.87 & 3.87 & 3.73 & 4.53 \\
\hline $\begin{array}{l}\text { Overall Organizational } \\
\text { Culture }\end{array}$ & 4.04 & 4.79 & 3.62 & 3.88 & 3.66 & 3.77 & 3.76 & 4.27 \\
\hline
\end{tabular}

Clan embraced the dominant organizational culture for current and preferred situations in consideration of its highest score among four types of organizational culture. The score of Clan was 4.04 for current organizational culture and increased to 4.79 for new hires' preferred situation. The Hierarchy culture was the second most dominant type for current and preferred organizational cultures. However, different organizational culture types obtained the lowest scores in the current and preferred organizational cultures. Adhocracy occupied the lowest score (3.62) in the current organizational culture, while Market culture was the least preferred organizational culture with a score of 3.77 .

Three organizational culture dimensions of the current and preferred organizational cultures were dominated by different organizational culture types. Firstly, the new hires perceived that the most significant organizational glue was the emphasis on Market culture (3.93), but they expected the organizational glue would be dominated by Clan culture (4.67). Secondly, the new hires perceived that the current strategic emphasis was dominated by Hierarchy (3.87), but they expected the Clan strategy (4.73). Finally, the new hires viewed the organizational leader in the current situation as Clan and Adhocracy characteristics (4.33), but they anticipated the organizational leader to comply with the Hierarchy culture (4.73).

\subsubsection{Organizational Culture of Existing Employees}

Fifty-three existing employees answered the questionnaire about organizational culture, and the results were presented in Table 5 .

Table 5. The organizational culture of existing employees

\begin{tabular}{|c|c|c|c|c|c|c|c|c|}
\hline \multicolumn{9}{|l|}{ Organizational Culture } \\
\hline $\begin{array}{l}\text { Dimensions of } \\
\text { Organizational Culture }\end{array}$ & $\begin{array}{l}\text { Current } \\
\text { Clan }\end{array}$ & $\begin{array}{l}\text { Preferred } \\
\text { Clan }\end{array}$ & $\begin{array}{l}\text { Current } \\
\text { Adhocracy }\end{array}$ & $\begin{array}{l}\text { Preferred } \\
\text { Adhocracy }\end{array}$ & $\begin{array}{l}\text { Current } \\
\text { Market }\end{array}$ & $\begin{array}{l}\text { Preferred } \\
\text { Market }\end{array}$ & $\begin{array}{l}\text { Current } \\
\text { Hierarchy }\end{array}$ & $\begin{array}{l}\text { Preferred } \\
\text { Hierarchy }\end{array}$ \\
\hline $\begin{array}{l}\text { Dominant Characteristics } \\
\text { of Organization }\end{array}$ & 4.13 & 4.66 & 3.43 & 3.34 & 3.64 & 4.00 & 3.11 & 3.34 \\
\hline Organizational Leadership & 4.28 & 4.68 & 4.28 & 4.60 & 3.68 & 3.85 & 4.04 & 4.58 \\
\hline $\begin{array}{l}\text { Management of } \\
\text { Employees }\end{array}$ & 4.06 & 4.64 & 2.96 & 3.11 & 3.04 & 3.13 & 4.17 & 4.66 \\
\hline Organizational Glue & 4.13 & 4.64 & 4.15 & 4.64 & 4.00 & 4.36 & 3.79 & 4.30 \\
\hline Strategic Emphases & 3.85 & 4.64 & 3.62 & 4.28 & 3.64 & 4.21 & 4.09 & 4.64 \\
\hline Criteria for Success & 4.25 & 4.83 & 4.04 & 4.62 & 3.68 & 4.02 & 3.92 & 4.43 \\
\hline $\begin{array}{l}\text { Overall Organizational } \\
\text { Culture }\end{array}$ & 4.12 & 4.68 & 3.75 & 4.10 & 3.61 & 3.93 & 3.86 & 4.33 \\
\hline
\end{tabular}

The current and preferred organizational culture types showed a similar sequence when ranked from the highest to the lowest scores. The sequence and scores for the current organizational culture were Clan (4.12), Hierarchy (3.86), Adhocracy (3.75), and Market (3.61). The scores for the preferred organizational culture were Clan (4.68), Hierarchy (4.33), Adhocracy (4.10), and Market (3.93). 
The current organizational culture dimensions as assessed by the existing employees appeared incongruent. Clan was highly perceived for the dominant characteristics of the organization (4.13) and the criteria for success (4.25). However, in terms of organizational leadership, Clan and Adhocracy received the same highest score (4.28). Hierarchy was dominated in two organizational culture dimensions including the management of employees (4.17) and strategic emphases (4.09). Finally, Adhocracy culture was perceived by the existing employees as the dominant culture in the organizational glue dimension (4.15).

The organizational culture dimensions of the preferred situation were more congruent than those of the current culture. Five organizational culture dimensions were dominated by Clan culture, including the dominant characteristics of the organization (4.66), organizational leadership (4.68), organizational glue (4.64), strategic emphases (4.64), and the criteria of success (4.83). However, the management of employees was the only organizational culture dimension varied from those five dimensions. It was dominated by Hierarchy culture (4.66).

\subsection{Organizational Culture Congruence between the New Hires and Existing Employees}

The congruence of the perceptions of organizational culture between the new hires and existing employees was observed in order to investigate the compatibility between the two groups of employees. Cultural congruence refers to the condition of the same dominant organizational culture in both groups. Figure 4 showed the current and preferred organizational cultures of the new hires and existing employees.

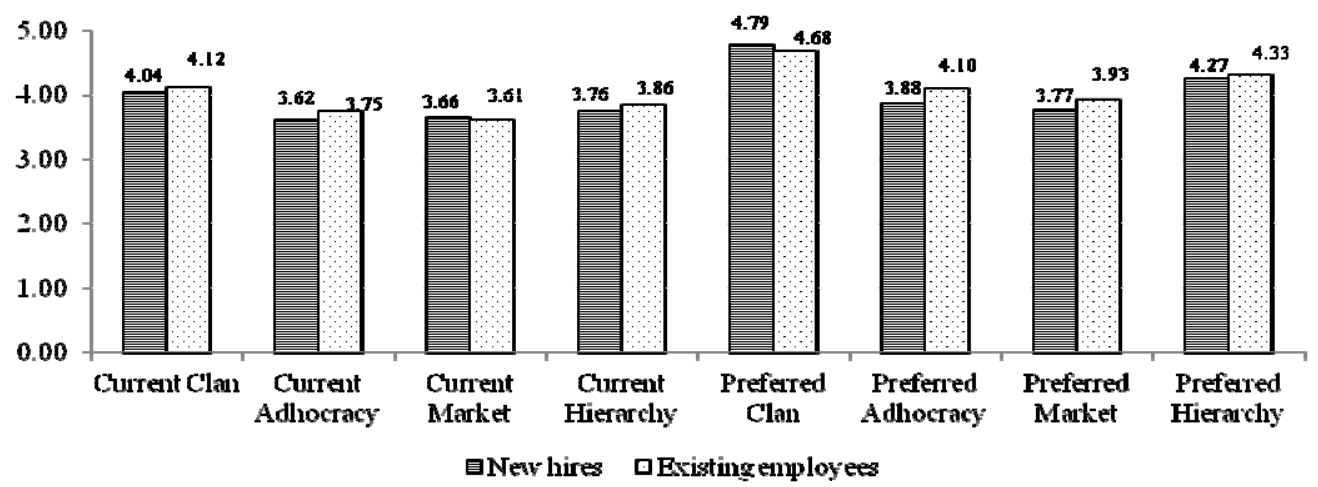

Figure 4. The current and preferred organizational cultures of the new hires and existing employees

Organizational cultures in both groups were dominated by Clan. In the current organizational culture, the scores for Clan by the new hires and existing employees were 4.04 and 4.12, respectively. Furthermore, the scores for Clan in the preferred organizational culture by the new hires and existing employees were 4.79 and 4.68 , respectively. Therefore, the organizational culture by the new hires was congruent to that culture by the existing employees.

\section{Discussion}

This study examines the organizational culture of a pharmaceutical company in Thailand by applying the Competing Values Framework (CVF). The results indicated that TRB Chemedica (Thailand), one of the leading pharmaceutical companies in the Thai artificial tear market, is dominated by Clan. The discussion of the findings will be presented hereafter in three topics: (a) the organizational culture of organizations in the pharmaceutical industry, (b) The possible factors that influence organizational culture, and (c) The organizational culture congruence between new hires and existing employees.

\subsection{The Organizational Culture of Organizations in the Pharmaceutical Industry}

The organizational culture of a pharmaceutical company in this study differed from the expected organizational culture of the pharmaceutical industry. A pharmaceutical company in Thailand was dominated by Clan, but pharmaceutical companies are actually expected to possess Adhocracy cultures. This assumption was established because pharmaceutical companies were anticipated to invent innovative treatments (Demir, Unnu, \& Erturk, 2010). The measured organizational culture of this pharmaceutical company in Thailand not only differed from the industry's expectation but also varied from the previous studies' results.

Thai pharmaceutical company's dominant organizational culture type appeared different from pharmaceutical 
companies in foreign countries. By applying the CVF and the OCAI, previous studies found that pharmaceutical companies in Turkey were dominated by Hierarchy culture (Demir, Unnu, \& Erturk, 2010). Another study reported that Adhocracy was dominated in Indian pharmaceutical companies (Gupta, 2011). Researchers have attempted to explain the possible factors that influence organizational culture: national culture, organizational age and organizational size (Chongruksut, 2009; Demir, Unnu, \& Erturk, 2010; Yazici, 2007).

\subsection{The Possible Factors that Influence Organizational Culture}

The determining factors influencing organizational culture have not been well understood, but researchers have indicated that organizational culture may be affected by national culture, organizational age, and organizational size. National culture may explain why the pharmaceutical company studied was dominated by Clan. According to Hofstede's cultural dimensions, Thailand is a highly collectivist nation characterized by a high level of commitment among members of the group. People are like an extended family and in-group relationships are significant. Furthermore, Thailand is a feminine society, indicating that Thai people are less competitive and value caring for each other (The Hofstede Centre, n. d.). These characteristics of Thai national culture highly resemble the description of Clan, which also values internal relationships and loyalty in the organization.

National culture's influence on organizational culture was consistent with earlier research in organizations in Thailand. Chongruksut (2009) applied the competing value model adapted from Van Muijen et al. (1999) to measure the organizational culture of companies listed on the Stock Exchange of Thailand. The responding companies predominately valued the "support organizational culture," which emphasized internal issues and the flexibility of organizations. These characteristics of the supporting organizational culture are similar to Clan in the CVF. Hence, the national culture, which represents collective national characters including values, beliefs, assumptions, and behavior, could be considered as one of critical factors shaping organizational culture.

Organizational age, which is the years of organizational establishment, possibly impacts organizational culture. TRB Chemedica (Thailand) Limited, which has been established in Thailand for 24 years, was dominated by Clan. This result was consistent with Yazici et al. (2007)'s study, which reported that organizations in operation for 16-25 years were dominated by Clan. The impact of organizational age on the type of organizational culture was explained by Cameron and Quinn (2006). At the earliest stage of the organizational life cycle, Adhocracy tends to be dominant because the company focuses on entrepreneurship. Then, Adhocracy is replaced by Clan because members in the organization foster intense relationships. However, organizational culture shifts to Hierarchy when a company faces crisis and needs standard policies to control the organization. Eventually, Market culture dominates as the company tends to move its focus from internal control to customer and external competition. Hence, organizational age may predict the dominant type of organizational culture.

Organizational size, that is, the number of employees, could be another factor that impacts organizational culture. Clan culture generally tends to be the dominant organizational culture of smaller organizations more often than large ones due to small organizations' simple organizational structure, ease of communication, close relationship between organizational members, and the democratic management styles (Connell, 2001). TRB Chemedica (Thailand) Ltd., a medium-sized organization employing 78 employees, was dominated by Clan culture. Likewise, Yazici et al. (2007) found that a medium-sized company (51-150 employees) in the Turkish construction industry had high scores for Clan and Hierarchy cultures.

\subsection{The Organizational Culture Congruence between New Hires and Existing Employees}

This study found organizational culture congruence between new hires and existing employees. Clan was the dominant type of organizational culture in both groups of employees. The findings indicated that employees espouse the same patterns of values, beliefs, and behaviors. This congruency enhances harmony among members in the organization. Consequently, the pharmaceutical company gains benefits because the employee turnover tends to decrease as a result of good relationships between employees. Furthermore, organizational culture congruence enhances the organizational effectiveness in the long run because employees have consistent organizational goals and strategies (Cameron \& Quinn, 2006). Therefore, organizational culture congruency among the new hires and existing employees is beneficial for the pharmaceutical company by minimizing employee turnover and enhancing organizational effectiveness.

\subsection{Managerial Implications and Recommendations for the Pharmaceutical Company}

Findings from this study provide two practical recommendations for the pharmaceutical company. First, the pharmaceutical company studied here can create a training program for organizational culture, which is a useful strategy to reduce the attrition rate in the pharmaceutical industry (Dhotre, 2010; Taylor, Levy, Boyacigiller, \& Beechler, 2008). After training, the new hires should correctly understand the organizational culture and 
assimilate into the organizational culture accordingly. For example, a new manager whose leadership style involves giving orders to control and coerce subordinates may not match with the clan-oriented organization which prefers to a parent-like relationship. Conflict between supervisors and subordinates usually leads to employee attrition. As a result, a new manager should be well oriented with the organizational culture, which covers the topic of leadership style. After training, the new manager will have a better understanding of the organizational culture and appropriately adapt to organizational culture. Training employees on the organizational culture prevents interpersonal conflicts and supports good relationship between members in the organization.

Second, the findings from this study recommend that TRB Chemedica (Thailand) Limited establish strategies to enhance the characteristics of its Clan culture. According to the results, the gap between the current and preferred Clan culture was the highest among the four types of organizational cultures. Furthermore, the dimension of organizational glue and strategic emphasis in the current organizational culture were dominated by Adhocracy and Hierarchy, respectively. They were not dominated by Clan, which was the preferred organizational culture. These findings indicate that the pharmaceutical company should develop three key strategies related to team building, relationship handling, and employee development to move the organizational culture toward the preferred Clan culture (Cameron \& Quinn, 2006).

\section{Conclusion}

The present study applied the CVF to investigate the organizational culture of a pharmaceutical company in Thailand. Moreover, the organizational culture congruence between the new hires and existing employees was observed. Clan was the dominant current and preferred organizational culture of the organization in Thai pharmaceutical industry. In addition, new hires and existing employees rated Clan as the dominant organizational culture. This study provided a better understanding of the organizational culture of an organization in the Thai pharmaceutical industry. As a result, it suggests that the pharmaceutical company may reduce employee turnover through the development of strategies to support Clan culture.

\section{Limitations}

Due to the small sample size of one pharmaceutical company in Thailand, this study may not be generalized to all companies in the pharmaceutical industry. Although companies operated within the same business environment, organizational culture varies from company to company (Zaheer, Rehman, \& Ahmad, 2006). Pharmaceutical companies are different in their organizational ages, organizational sizes, and business ownership structures (i.e., a government-owned corporation or a private-owned corporation, a local company or a multinational enterprise). Hence, careful consideration should be made in terms of the generalizability of this study.

Despite some limitations, this study possessed two specific characteristics. First, this study reveals the actual organizational culture of a pharmaceutical company regarding the data obtained from all employees (i.e., management-level to operating-level employees). The data collection method of the present study is different from the inclusion criteria of previous studies, which included only the chief executives or a few representatives of the companies (Chongruksut, 2009; Gupta, 2011). Second, this study observes the organizational culture in two employee groups: new hires and existing employees. The measurement of organizational culture by these groups of employees could indicate organizational culture congruency and help establish the strategies to foster relationships.

\section{Suggestions for Further Studies}

Two perspectives are recommended to extend the current knowledge on organizational culture in the pharmaceutical industry. First, the measurement of organizational culture in this study provides a better understanding of the pharmaceutical company's characteristics (e.g., leadership style, employee management, and bonding mechanism). Hence, researchers and leaders of pharmaceutical companies should assess their organizational cultures to support a clearer understanding of their organizations. Second, this study investigates the dominant organizational culture, but it does not prove the relationship between organizational culture and other variables. Further research should investigate the impacts of organizational culture on turnover intention and their interesting determinants. The greater the understanding of organizational culture is, the greater the benefits pharmaceutical companies will obtain to improve their performance. 


\section{References}

Aswapokee, S. (2007). The relationship and impact between information system characteristics and organizational culture on job satisfaction in pharmaceutical companies in Thailand (Master's thesis). Retrieved from Thai Library Integrated System.

Aydogdu, S., \& Asikgil, B. (2011). The effect of transformational leadership behavior on organizational culture: An application in pharmaceutical industry. International Review of Management and Marketing, 1(4), 65-73. Retrieved from http://www.econjournals.com

Burrill \& Company. (2011, July 29). Merck to Cut Up to 13,000 Jobs by 2015. Retrieved from http://www.burrillreport.com

Cameron, K. S., \& Quinn, R. E. (2006). Diagnosing and changing organizational culture based on the Competing Value Framework (Revised ed.). San Francisco, CA: Jossey-Bass A Wiley Imprint.

Chimthai, P. (2009). Organizational culture, organizational commitment and employee's performance effectiveness in Government Pharmaceutical Organization (Unpublished master's project). Srinakharinwirot University, Thailand.

Chongruksut, W. (2009). Organizational Culture and the Use of Management Accounting Innovations in Thailand. Ramkhamhaeng University International Journal, 3(1), 113-126.

Chotiwongse, N. (2001). Organizational culture. Strategic Management Tools and Ideas (pp. 71-116). Bangkok, Thailand: Royal Press and Pack Co., Ltd.

Connel, J. (2001). Influence of firm size on organizational culture and employee morale. Journal of Management Research, 1(4), 220-230.

Dan, F., \& Petersen, J. C. (1984). Commitment, absenteeism, and turnover of new employees: A longitudinal study. Human Relations, 37, 681-692. Retrieved from http://libres.uncg.edu/ir/uncg/f/J_Petersen Commitment_1984.pdf; http://dx.doi.org/10.1177/001872678403700807

Demir, C., Unnu, N. A., \& Erturk, E. (2010). Diagnosing the organizational culture of a Turkish pharmaceutical company based on the competing values framework. Journal of Business Economics and Management, 12(1), 197-217. http://dx.doi.org/10.3846/16111699.2011.555451

Deshpande, R., \& Webster, F. E. (1989). Organizational culture and marketing: Defining the research agenda. Journal of Marketing, 53(1), 3-15. http://dx.doi.org/10.2307/1251521

Dhotre, A. (2010). Attrition in pharmaceutical industry: Human resources management's role and strategy. International Research Journal, 1(11), 87-89. Retrieved from http:/www.ssmrae.com/admin/images/0ea $3861 \mathrm{cf0d0} 96 \mathrm{caf0b1048517f1b428.pdf}$

Dilokgomon, C. (2003). Organizational culture and learning organization: Context in Better Pharma Co., Ltd. (Master's thesis). Retrieved from Thai Library Integrated System.

Gupta, B. (2011). A comparative study of organizational strategy and culture across industry. Benchmarking: An International Journal, 18(4), 510-528. http://dx.doi.org/10.1108/14635771111147614

Hildebrand, D. S. (2010). Top four mistakes new hires make. Retrieved from http://www.suite101.com

Jung, T., Scott, T., Davies, H. T., Bower, P., Whalley, D., McNally, R., \& Mannion, R. (2009). Instruments for exploring organizational culture: A review of the literature. Public Administration Review, 69(6), 1087-1096. http://dx.doi.org/10.1111/j.1540-6210.2009.02066.x

Li, Z. (2011). Healthcare and the road to Asean Economic Community (AEC) in 2015. Retrieved from http://thailand-business-news.com

Martin, M. J. (2006). That's the way we do things around here: An overview of organizational culture. Electronic Journal of Academic and Special Librarianship, 7(1). Retrieved from http://southernlibrarianship.icaap.org

McShane, S. L., \& Von Glinow, M. A. (2002). Organizational culture. Organizational behavior (pp. 445-471). NY: McGraw-Hill/Irwin.

Nagashekhara, M., \& Agil, S. O. (2012). Does organizational culture influence the ethical behavior in the pharmaceutical industry? Journal of Basic and Clinical Pharmacy, 3(1), 219-223. Retrieved from http://www.jbclinpharm.com; http://dx.doi.org/10.4103/0976-0105.103828 
OCAI Online. (n. d.). Organizational culture assessment instrument online. Retrieved from http://www.ocaionline.com/ocai/one/introduction

Odom, R. Y., Boxx, W. R., \& Dunn, M. G. (1990). Organizational cultures, commitment, satisfaction and cohesion. Public Productivity \& Management Review, 14(2), 157-169. http://dx.doi.org/10.2307/3380963

Ongori, H. (2007). A review of the literature on employee turnover. African Journal of Business Management, 49-54. Retrieved from http://www.academicjournals.org/ajbm

Pierson, R. (2013). Merck to slash annual costs by $\$ 2.5$ billion, cut 8,500 jobs. Reuters. Retrieved from http://www.reuters.com

Poonsawat, P. (2005). Organizational culture and teachers' organizational commitment in the office of Nakhonpathom Education Service Area (Master's thesis). Retrieved from http://www.thapra.lib.su.ac.th/ objects/thesis/fulltext/snamcn/Pisit_Poonsawat/Fulltext.pdf

Schein, E. H. (2004). Organizational Culture and Leadership (3rd ed.). San Francisco, CA: Jossey-Bass.

Silverthorne, C. (2004). The impact of organizational culture and person-organization fit on organizational commitment and job satisfaction in Taiwan. Leadership \& Organization Development Journal, 25(7), 592-599. http://dx.doi.org/10.1108/01437730410561477

Sutarjo. (2011). Ten ways of managing perosn-organization fit (P-O Fit) effectively: A literature study. International Journal of Business and Social Science, 2(21), 226-233.

Taylor, S., Levy, O., Boyacigiller, N. A., \& Beechler, S. (2008). Employee commitment in MNCs: Impacts of organizational culture, HRM and top management orientations. The International Journal of Human Resource Management, 19(4), 501-527. http://dx.doi.org/10.1080/09585190801953491

Thailand Board of Investment. (2011). Investment Opportunities Ripen in Thai Pharmaceutical Industry. Thailand Investment Review, 21(8), 1-4. Retrieved from http://www.boi.go.th/tir/issue/201108_21_8/ document.pdf

The Hofstede Center. (n. d.). What about Thailand? Retrieved from http://geert-hofstede.com/thailand.html

The Human Capacity on Building Institute. (n. d.). The Survey on Salaries and Welfares. Retrieved from http://www.hcbi.org

Vandenberghe, C. (1999). Organizational culture, person-culture fit, and turnover: A replication in the health care industry. Journal of Organizational Behavior, 20(2), 175-184. http://dx.doi.org/10.1002/(SICI) 1099-1379(199903)20:2<175::AID-JOB882>3.0.CO;2-E

Wilton, P. (2006). Pharma's big turnover. Pharmaceutical Frontier, 11. Retrieved from http://www.worldpha rmaceuticals.net/pdfs/011_WPF010new.pdf

Yang, J. T. (2008). Effect of newcomer socialisation on organisational commitment, job satisfaction, and turnover intention in the hotel industry. The Service Industries Journal, 28(3), 429-443. http://dx.doi.org/10. $1080 / 02642060801917430$

Yazici, E. O., Giritly, H., Oraz, G. T., \& Acar, E. (2007). Organizational Culture: The Case of Turkish Construction Industry. Engineering, Construction and Architectural Management, 14(6), 519-531. http://dx.doi.org/10.1108/09699980710828996

\section{Copyrights}

Copyright for this article is retained by the author(s), with first publication rights granted to the journal.

This is an open-access article distributed under the terms and conditions of the Creative Commons Attribution license (http://creativecommons.org/licenses/by/3.0/). 